\title{
TOWARDS AN EFFECTIVE LEGAL FRAMEWORK FOR ONLINE DISPUTE RESOLUTION IN E-COMMERCE TRANSACTIONS: TRENDS, TRADITIONS, AND TRANSITIONS
}

\author{
Sodiq O. Omoola* \\ Umar A. Oseni*
}

\begin{abstract}
The need for convergence of best practices in Alternative Dispute Resolution (ADR) and Information and Communication Technology (ICT) cannot be overemphasised in an increasingly digitalised world. This undoubtedly led to the introduction of Online Dispute Resolution (ODR) few decades ago which is considered a fast, seamless, and convenient means of dispute resolution. With the increasing prominence of e-commerce transactions, several countries and regions of the world are on the quest to provide an effective legal framework for ODR in ecommerce dealings. This article analyses the approaches to ODR legislations for consumer protection in selected jurisdictions. The article finds that a comparative legal approach with some leverage on legal borrowing can help to create the required legal environment for ODR in other jurisdictions.
\end{abstract}

Keywords: ADR, consumer protection, e-commerce, ICT, Online Dispute Resolution

Ph.D. Candidate, Ahmad Ibrahim Kulliyyah of Laws, International Islamic University Malaysia

** Associate Professor, Ahmad Ibrahim Kulliyyah of Laws, International Islamic University Malaysia. 


\title{
KE ARAH KERANGKA UNDANG-UNDANG YANG BERKESAN BAGI PENYELESAIAN PERTIKAIAN DALAM TALIAN YANG BERKESAN UNTUK TRANSAKSI E- PERDAGANGAN: TREND, TRADISI DAN PERALIHAN
}

\begin{abstract}
ABSTRAK
Keperluan kepada amalan terbaik dalam Penyelesaian Pertikaian Alternatif (ADR) dan Teknologi Informasi dan Komunikasi (ICT) tidak dapat di nafikan di dalam dunia digital masa kini. Perkara ini telah menyebabkan pengenalan kepada Penyelesaian Pertikaian Atas Talian (ODR) sejak beberapa dekad yang lalu kerana ianya di lihat sebagai cara yang cepat, lancer dan mudah bagi menyelesaIkan masaalah. Dengan penekanan yang diberikan kepada transaksi eperdagangan, beberapa negara rantau di dunia ini mempunyai misi untuk memberikan kerangka undang-undang yang efektif untuk penyelesaian pertikaian atas talian dalam kes-kes e-perdagangan. Makalah ini menganalisa pendekatan undang-undang bagi penyelesaian pertikaian atas talian yang terdapat di negara-negara yang terpilih. Makalah ini mendapati bahawa pendekatan secara perbandingan dengan mengguna pakai kaedah peminjaman undangundang boleh membantu dalam mencipta persekitaran undangundang yang sesuai untuk pemakaian penyelesaian pertikaian atas talian di antara negara.
\end{abstract}

Kata Kunci: Penyelesaian Pertikaian Alternatif (ADR), perlindungan pengguna, e-perdagangan, Teknologi Informasi dan Komunikasi (ICT), Penyelesaian Pertikaian Atas Talian (ODR) 


\section{INTRODUCTION}

Given the volume of electronic and small scale financial transactions that are initiated every minute across the globe and the fact that Information and Communication Technology (ICT) has enhanced commerce beyond physical contact, it has since become apparent that a new regime is required for the resolution of disputes. ${ }^{1}$ The nature of disputes which are generated from online financial transactions are known to be 'high volume low value claims' which are either too low to pursue in the law court or consumers simply but painfully ignore them due to the high cost and time of accessing justice. ${ }^{2}$ Consequently, the consumers who were technically compelled to part with funds resulting from a failed transaction desist from shopping. This implies that trust is lost and the financial institution and the ecommerce platforms loose more potential financial consumers.

Despite the viability of adopting Alternative Dispute Resolution (ADR) mechanisms such as negotiation, mediation, conciliation and other hybrid processes to resolve financial disputes, such effective mechanisms could be daunting or defeated by time and distance. The traditional approach to resolving small claims financial disputes primarily involve a visit to the customer service desk or placing a call to the call centre. The efficacy of the former for a consumer who is restricted by time and space remains while the latter is at the mercy of long queues or being placed on hold to submit a complaint. These two situations have several limitations which are not suitable for the exigencies of modern ICT driven financial transactions. That is, such traditional ways of dispute management of small claims financial disputes are generally offline, slow and may lead to more cost on the part of the consumer. Therefore, the demand for new forms of ICTbacked ADR becomes a necessity. ${ }^{3}$

OECD, Guidelines for Consumer Protection in the Context of Electronic Commerce (OECD Publishing, 2000).

2 Louis Del Duca, Colin Rule, and Zbynek Loebl, "Facilitating Expansion of Cross-Border E-Commerce-Developing a Global Online Dispute Resolution System (Lessons Derived from Existing ODR Systems-Work of the United Nations Commission on International Trade Law)," Penn State Law Legal Studies Research Paper, no. 25-2011 (2011).

3 DA Larson, "Technology Mediated Dispute Resolution (TMDR): Opportunities and Dangers," U. Tol. L. Rev., 2006, 213-38; Henry H Perritt Jr, "Dispute Resolution in Cyberspace: Demand for New Forms of ADR," Ohio St. J. on Disp. Resol. 15 (1999): 675. 
In the recent past, there have been several attempts to protect consumers from unfair loss of funds through the use of ICT enabled algorithm to provide neutral, cheap and real time resolution of disputes. These attempts have been largely based on private and public experiments in the United States and Europe. One of the experiments have translated to a huge success by Squaretrade/eBay which successfully resolved over 60 million disputes as at $2010 .{ }^{4}$ Whether national, regional or international regulation can adequately deploy a practical ODR framework for online consumers is yet to be seen in the e-commerce industry. ${ }^{5}$ There have been earlier attempts to explore the feasibility of ODR in some specialised industries such as the Islamic finance industry ${ }^{6}$ and the e-commerce sector ${ }^{7}$.

Nevertheless, there has not been much attempt to examine the different approaches for ODR legislations for consumer protection with special reference to e-commerce. This article therefore seeks to fill this void by examining the existing legal framework for ODR mechanisms and different permutations at regional and national levels. Specifically, the EU Consumer ODR framework, Organisation of American States (OAS) efforts and other international efforts are closely examined. This study also examines some best practices in the use of ODR in the resolution of consumer disputes such as credit reporting, insurance claims and e-commerce excluding online frauds and scams which is criminal in its nature.

Against the above backdrop, this article is organised to examine distinct but conceptually related fields. A general overview of the concept of ODR with specific focus on its recent history and development is discussed. The desirability and the different paradigms in ODR services are also analysed along with some best practices in the use of ODR in consumer and financial dispute resolution. The core of the study explores the different approaches to ODR legislation in selected jurisdictions with a view to providing

4 Steve Abernethy, "Building Large-Scale Online Dispute Resolution \& Trustmark Systems," UNECE Forum on ODR, 2003.

5 Umar A. Oseni and Sodiq O. Omoola, "Banking on ICT: The Relevance of Online Dispute Resolution in the Islamic Banking Industry in Malaysia," Information \& Communications Technology Law 24, no. 2 (August 17, 2015): 205-23.

6 Ibid.

7 Lucile M. Ponte and Thomas D. Cavenagh, CyberJustice: Online Dispute Resolution $(O D R)$ for E-Commerce (Upper Saddle River, NJ, USA: PrenticeHall, Inc., 2004). 
examples for other jurisdictions, particularly the developing countries. Models can be emulated and adapted to enhance e-commerce dispute resolution. The article concludes with some policy recommendations and suggestion for ODR legal framework.

\section{THE CONCEPT OF ODR: AN OVERVIEW}

Online Dispute Resolution emerged in the $21^{\text {st }}$ Century from developments in the field of Alternative Dispute Resolution (ADR) and its adaptability to peculiarities of the online environment. ${ }^{8}$ In addition, it was primarily borne out of the need to deploy cutting-edge information technology innovation to aid access to justice. ${ }^{9}$ In the past decades, automation of service delivery was perceived as a threat to labour in the non-legal sectors with job cuts, due to a technological takeover of clerical jobs such as cashier, secretaries and bookkeepers. ${ }^{10}$ In the justice delivery sector, experts predict a paradigm shift in the way lawyers perform their jobs towards automation of the dispute resolution processes. ${ }^{11}$ This might be seen as threatening the traditional methods of justice delivery.

ODR can also be understood from the convergence perspective, i.e., dispute resolution converges with ICT. As part of the fulfilments of the Roscoe Pound ${ }^{12}$ and Lord Woolf Reforms, ${ }^{13}$ court systems

8 Ethan Katsh, M Ethan Katsh, and Janet Rifkin, Online Dispute Resolution: Resolving Conflicts in Cyberspace (John Wiley \& Sons, Inc., 2001).

9 Ethan Katsh, "ODR: A Look at History - A Few Thoughts About the Present and Some Speculation About the Future," in Online Dispute Resolution: Theory and Practice A Treatise on Technology and Dispute Resolution, ed. Mohamed S. Abdel Wahab, Katsh Ethan, and Rainey Daniel (The Hague, Netherland: Eleven International Publishing, 2012), 21-33.

10 R Howard and L Schneider, "Technological Change as a Social Process: A Case Study of Office Automation in a Manufacturing Plant," Central Issues in Anthropology 7, no. 2 (1988): 79-84.

11 B Rose, "NO WAY BACK: Don't Look Now, but a Technology Revolution Is Changing the Way Lawyers Work," ABA Journal, 2009.

12 Roscoe Pound, "The Causes of Popular Dissatisfaction with the Administration of Justice," Annu. Rep. ABA 29 (1906): 395-417; WD Brazil, "Court ADR 25 Years After Pound: Have We Found a Better Way," Ohio St. J. Disp. Resol. 1 (2002).

13 AAS Zuckerman, "Lord Woolf's Access to Justice: Plus Ça Change," The Modern Law Review 59, no. 6 (1996): 773-96; "Farmers and 'Prostitutes ': Twentieth-Century Problems of Female Inheritance in Kano Emirate , Nigeria Author ( $S$ ): Steven Pierce Reviewed Work ( S ): Published by: Cambridge 
globally have incorporated ADR mechanisms in the administration of justice. Thus, amicable dispute settlement paradigms have found their ways into regional and international legal instruments. ${ }^{14}$ Without doubt, ADR has proved to be the most suitable and cost-effective method for resolving disputes arising from commercial and financial transactions in recent years. However, new challenges posed by ecommerce and the growing number of cross-border small claim online disputes call for reform of ADR itself. Lack of a regulatory framework for stringent management of complaint is capable of clogging the justice system with high volume small claims. ${ }^{15}$ Courts are often clogged with expensive, congested, and protracted procedures and formality. This results in long delay as decision may take even years before a judgment sees the light of the day, and the economic or even emotional costs involved can be devastating for consumers. ${ }^{16}$

In the administration of justice system, an effective ODR paradigm has the potential of automating the dispute resolution processes which experts predict may soon threaten the legal profession and change the way lawyers do their businesses. ${ }^{17}$ Indeed, the dispute resolution sector of the modern society got its fair share of innovative technology with the emergence of ODR. Richard Susskind $^{18}$ was aptly referring to ODR and the changing role of lawyers when he observed:

University Press" 44, no. 3 (2013): 463-86; LA Mistelis, "ADR in England and Wales," Am. Rev. Int'l Arb. 12 (2001): 167-441.

14 Steven Smith et al., "International Commercial Dispute Resolution," Int'l Law. 44 (2010): 113.

15 C Rule, V Rogers, and L Del Duca, "Designing a Global Consumer Online Dispute Resolution (ODR) System for Cross-Border Small Value-High Volume Claims - OAS Developments," UCC LJ, no. 24 (2010): 221.

16 S Schiavetta, "Online Dispute Resolution, E-Government and Overcoming the Digital Divide," BILETA Conference, April, 2005.

17 Rose, "NO WAY BACK: Don't Look Now, but a Technology Revolution Is Changing the Way Lawyers Work."

18 Professor Richard Susskind OBE is an author, and independent adviser to major professional firms and to national governments. He is also the technology advisor to the Lord Chief Justice of England and Wales. His main area of expertise is the future of professional services and, in particular, the way in which the IT and the Internet are changing the work of lawyers. He has worked on legal technology for over 30 years. He lectures internationally, has written many books, and advised on numerous government inquiries. www.susskind.com 
The future of lawyers could be prosperous or disastrous...lawyers who are unwilling to change their working practices and extend their range of services will, in the coming decade, struggle to survive. Meanwhile, those who embrace new technologies and novel ways of sourcing legal work are likely to trade successfully for many years... ${ }^{19}$

The evolution of the use of ICT tools in legal services seems to attest to this assertion. The incorporation of innovative ICT equipment and technology into dispute resolution mechanisms began with taking evidence via video-conferencing, case-management software and online filing applications and admitting electronic copy of documents. This was viewed as a mere aid to the judicial process, which was easier and faster as parties could access justice at a cheaper cost; hence, the emergence of courts facilitated by ICT, where the procedural steps mimic the court systems. Cyber courts and cyber tribunals are studied differently from ODR. While the former is the adaptation of technology to court procedures, the latter is the use of technology partly or wholly in ADR processes. ${ }^{20}$ However, the distinction could be blurred where courts provide ADR service, i.e. court-annexed mediation. The situation has been described thus:

Cybercourts are simply court proceedings that use exclusively (or almost exclusively) electronic communication means. They should be, and often are, considered to be part of the ODR movement, for two reasons. First, because the ODR movement emerged because of the clash between the ubiquity of the Internet and the territoriality of traditional, offline dispute resolution mechanisms. The term ODR is thus opposed to offline dispute resolution mechanisms, not to courts. Online ADR is only one part of ODR. Second, courts do not only provide litigation. As I said before, there also is court-based mediation and non-binding arbitration. ${ }^{21}$

In essence, such feat recorded in the administration of justice system led to integration of such technological advancement into

19 R Susskind, The End of Lawyers?: Rethinking the Nature of Legal Services (Oxford University Press, 2010), 269.

20 MM Albornoz, "Feasibility Analysis of Online Dispute Resolution in Developing Countries," U. Miami Inter-Am. L. Rev. 44, no. 2 (2012): 126.

21 Thomas Schultz, "An Essay on the Role of Government for ODR: Theoretical Considerations about the Future of ODR," ADR Online Monthly UMASS 7, no. 8 (2003): 5 . 
traditional ADR mechanisms; hence, the emergence of terms such as 'Online Mediation', 'Online Arbitration', etc. ${ }^{22}$

Researchers have been inconsistent with the nomenclature of ODR in its early stage, as it is variously known as Electronic Dispute Resolution (EDR), ${ }^{23}$ Internet Dispute Resolution (IDR), ${ }^{24}$ Online Alternative Dispute Resolution (OADR), ${ }^{25}$ and Technology Mediated Dispute Resolution (TMDR). ${ }^{26}$ However, regardless of the name used, most seem to have agreed that there is an increasing convergence between dispute resolution and ICT, which translates to a new regime for dispute resolution. The phrase "Online Dispute Resolution" has now become the most widely used term while referring to ICT-enabled dispute resolution, particularly when it is conducted online.

Notwithstanding the significant progress in the integration of ICT and ADR mechanisms, it is believed that ADR has not achieved its desired result where dispute arose from transactions, which were conducted partly or wholly in the cyberspace. Where the value claim in a dispute is subject to commercial courts, the ability of the court to hand-down decision in real time at low cost to the parties is put to test. Traditional courts are grappling with appropriate approaches to resolve e-commerce disputes which are mostly small-claims but high volume. The cost of obtaining justice may well be higher than the claim. $^{27}$

Major breakthroughs in the interaction between dispute resolution and ICT occurred in the mid-1990s when the Villanova University established the Virtual Magistrate, and University of Massachusetts' Online Ombuds Office. The Virtual Magistrate Project offered

Jerome Orji Uchenna, “Technology Mediated Dispute Resolution: Challenges and Opportunities for Dispute Resolution," Computer and Telecommunication Law Review 18, no. 5 (2012): 126.

23 B Baumann, "Electronic Dispute Resolution (EDR) and the Development of Internet Activities," Syracuse L. Rev. 52 (2002): 1227.

24 B.F Dusty, "A New Automated Class of Online Dispute Resolution: Changing the Meaning of Computer Mediated Communication.," Faulkner Law Review, 2011.

25 HA Haloush and BH Malkawi, "Internet Characteristics and Online Alternative Dispute Resolution," Harv. Negot. L. Rev. 13 (2008): 327-49.

26 Uchenna, "Technology Mediated Dispute Resolution: Challenges and Opportunities for Dispute Resolution."

27 Pablo Cortés, "Developing Online Dispute Resolution for Consumers in the EU: A Proposal for the Regulation of Accredited Providers," International Journal of Law and Information ... 19, no. 1 (2011): 3. 
arbitration for rapid, interim resolution of disputes involving: system administrators, parties in an online system and those who were harmed by online postings, including files and documents. ${ }^{28}$ Both the Ombuds and virtual magistrate were University sponsored pilot projects.

It is pertinent to clarify that identifying a real ODR platform depends on the nature of ICT mechanism deployed. Conley Tyler and Summer Raines observed:

Simply providing information about ADR on a website is not ODR: some dispute process must be attempted. A range of communication methods can be used, including: Email - a virtually instantaneous transfer of mainly text messages, Instant Messaging - a variant on email that allows synchronous online chat, Online Chat - a synchronous, text-based exchange of information, Threaded Discussion (also known as bulletin boards) - an asynchronous, textual exchange of information organized into specific topics, Video/Audio Streams - asynchronous transfer of recorded messages, and Videoconferencing - synchronous transfer of video information. ${ }^{29}$

The following sections give few of the possible permutations or manifestations of ODR which can be deployed for fast, cheap and party-driven dispute resolution.

\section{Desirability of ODR}

In addition to the physical barriers which have been broken down by the ICT revolution, the volume of commercial activities entered into on the web make settling disputes online appealing. ${ }^{30}$ Despite the growth of internet enabled financial transactions, the legal regime for the resolution of small claims disputes has been on its lowest ebb. Customer relation management (CRM) deployed for management of complaints lacks the requisite legal framework for neutral, transparent and speedy resolution of financial disputes. The CRM model only constitutes a set of remedial measures that are only matters of internal

28 Frank A. Cona, "Focus On cyberLaw: An Application of Online Systems in Alternative Dispute Resolution," Buffalo Law Review 45 (1997): 975.

29 SS Raines and M Conley Tyler, "From E-Bay to Eternity: Advances in Online Dispute Resolution," in Presented at the 8th Annual Conference of the American Bar Association's Section on Dispute Resolution April 5th-8th, 2006 Atlanta, GA, 2006.

30 Perritt Jr, "Dispute Resolution in Cyberspace: Demand for New Forms of ADR." 
management policy. These policies, which are customer-focused, are aimed at maximising revenue, and serve as customer retention strategies rather than consumer protection. ${ }^{31}$

Moreover, most consumer protection institutions provide redress for consumers using traditional offline mechanisms without the option of online methods. The time and amount of claim are two vital determinants for consideration before complaint is filed by an online consumer. Therefore, consumers may choose to relinquish their rights due to the hardship which might occur in offline dispute mechanisms. ODR researchers ${ }^{32}$ have identified some of the advantages of conducting ADR procedures online as follows: immediate access to justice for small claims; court decongestion and small claims; consumer trust and confidence; party autonomy and privacy; easy cross-border transactions; and environmental Sustainability. The overall advantages of $\mathrm{ODR}^{33}$ as opposed to traditional ADR in specific disputes have been examined in previous literature and it is needless to dwell on this in this section.

\section{Paradigms in ODR Services}

ODR can be simply explained as taking dispute resolution to the cyberspace or dispute resolution mechanisms conducted through the web-enabled applications. In other words, ODR includes ADR mechanisms that are facilitated through the use of modern ICT

31 Jan U Becker, Goetz Greve, and Sönke Albers, “The Impact of Technological and Organizational Implementation of CRM on Customer Acquisition, Maintenance, and Retention," International Journal of Research in Marketing 26, no. 3 (2009): 207-15.

32 JW Goodman, "The Pros and Cons of Online Dispute Resolution: An Assessment of Cyber-Mediation Websites," Duke Law \& Technology Review 176, no. 1998 (2003): 1-16; Katsh, "ODR: A Look at History - A Few Thoughts About the Present and Some Speculation About the Future"; Rule, Rogers, and Duca, "Designing a Global Consumer Online Dispute Resolution (ODR) System for Cross-Border Small Value-High Volume Claims-OAS Developments"; Oseni and Omoola, "Banking on ICT: The Relevance of Online Dispute Resolution in the Islamic Banking Industry in Malaysia."

33 Goodman, "The Pros and Cons of Online Dispute Resolution: An Assessment of Cyber-Mediation Websites"; Katsh, "ODR: A Look at History - A Few Thoughts About the Present and Some Speculation About the Future"; Rule, Rogers, and Duca, "Designing a Global Consumer Online Dispute Resolution (ODR) System for Cross-Border Small Value-High Volume Claims-OAS Developments"; Oseni and Omoola, "Banking on ICT: The Relevance of Online Dispute Resolution in the Islamic Banking Industry in Malaysia." 
equipment. ADR mechanisms are known for their flexibilities and ability to take different forms depending on the nature of the dispute. Thus, ADR methods can be adapted to establish flexible ODR platforms for e-commerce consumer dispute resolution.

Basically, it can be concluded that an ODR provider is an online platform that possesses the ability to deliver any ADR procedure in real-time. Figure 1 shows the various possible permutations of ODR, each permutation being a product of the existing ADR mechanism and innovative ICT techniques.

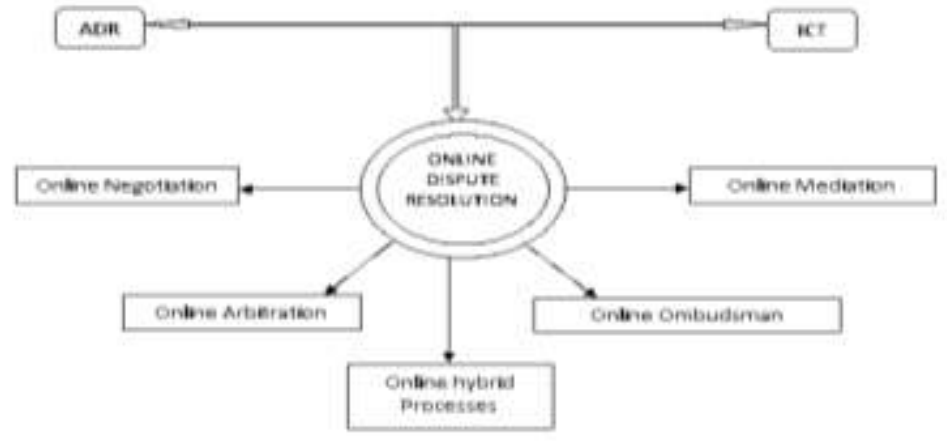

Source: Authors

Figure 1: Possible permutations of ODR

Some of the ODR techniques which have been examined in existing literature include but not limited to Online Ombudsman ${ }^{34}$, Online Negotiation ${ }^{35}$, Online Mediation ${ }^{36}$, Online Arbitration ${ }^{37}$ among others. This translates to more ways of seeking redress for online disputes, without the need for travel or physical presence at a dispute

34 Frank Fowlie, "Online Dispute Resolution and Ombudsmanship.," in Online Dispute Resolution: Theory and Practice A Treatise on Technology and Dispute Resolution, ed. Mohamed S Abdel Wahab, Ethan Katsh, and Daniel Rainey (The Netherland: Eleven International Publishing, 2012), 325-40.

35 Ernest Thiessen, Paul Miniato, and Bruce Hiebert, "ODR and eNegotiation," in Online Dispute Resolution: Theory and Practice A Treatise on Technology and Dispute Resolution, ed. Mohamed S Abdel Wahab, Ethan Katsh, and Daniel Rainey (The Netherland: Eleven International Publishing, 2012), 341-68.

36 Josep Suquet-capdevila, "Exploring Online Consumer Mediation in Catalonia : Principles and Technological Uses," International Journal of Law and Information Technology 20 (2012): 1-20.

37 AJ Schmitz, "Drive-Thru Arbitration in the Digital Age: Empowering Consumers through Binding ODR," Baylor L. Rev. 62, no. 10 (2010): 178. 
resolution centre. Each mechanism can be categorised as technologybased or technology-assisted process based on the quantum of online procedures involved in the platform.

\section{SOME BEST PRACTICES IN THE USE OF ODR IN CONSUMER AND FINANCIAL DISPUTE RESOLUTION}

Since the emergence of ODR in the early 1990s, several trial and pilot projects had been carried out to examine the efficacy of ODR in the resolution of both offline and online disputes. As at 2005, it was reported that there were about 115 ODR sites dealing with different kinds of disputes including but not limited to issues on family, workplace, e-commerce, insurance, among others. ${ }^{38}$ While many of the sites were pilot projects and experiments, the US based National Centre for Technology and Dispute Resolution is compiling a list of existing ODR Providers, which are currently operational with 68 providers on the list. ${ }^{39}$

However, it is necessary to discuss few of the successful and epochmaking ODR start-ups. This will lay the foundation for appropriate

38 Katsh, "ODR: A Look at History - A Few Thoughts About the Present and Some Speculation About the Future."

39 Available at <http://odr.info/provider-list/> viewed on 20 June 2016. The following are the notable ODR Providers in the world captured in the list which is still being updated: American Arbitration Association (AAA), ADNDRC, ADRoit3, Appellex Bargaining Solutions, Arbitranet, ARyME, Better Business Bureau Online, Camera Arbitrale di Milano, CaseloadManager.com, Chartered Institute of Arbitrators, Cibertribunal peruano, Conflict Resolution Software, Consensus Mediation, Consumers association of Iceland, Conflict Resolution.com, Convirgente.com, CPR Institute for Dispute Resolution, Crowdjury.org, Cyberlaws.Net, Cybersettle, Dispute Manager, eadronline. www.econfianza.org, Electronic Consumer Dispute Resolution (ECODIR), ElectronicCourthouse.com, EmissaryMediation.com, eQuibbly.com, Eurochambres, FSM, GWMK, Hong Kong International Arbitration Centre, iCan Systems Inc. (Smartsettle), ICANN Ombudsman Office, iCourthouse, International Chamber of Commerce, Iudica, The Internet Ombudsman, Intersettle, Iris Mediation, IVentures, JAMS, Judge.me, Juripax, Legal Face-Off, Mediation Arbitration Resolution Services (MARS), Mediation in the Clouds, Mediation Now, The Mediation Room, MESUTRAIN, MichiganCybercourt.Net, Modria.com, ODR.NL, ODRWorld, PeopleClaim, Private Judge, Resolution Forum Inc., SettleTheCase, SettleToday, Simediar, Smartsettle Family Resolutions, SquareTrade, The Claim Room, TRUSTe, Ujuj, VirtualCourthouse, The Virtual Magistrate, Webmediate.com, World Intellectual Property Organization (WIPO) 
model, which can be suited for consumer disputes. Aspects of ODR in e-commerce as operated by SquareTrade/eBay will be discussed being the first and most successful ODR project, which has survived till date. Insurance claim ODR as deployed by Cybersettle subject to some adaptations can be a good basis for ODR in developing countries. Several of such experiments have found their ways into the industry such as e-commerce, insurance credit reporting among other sectors.

\section{The eBay/SquareTrade Experiment}

The eBay/SquareTrade ODR is one of the most successful projects in the early development of ODR. Founded in the mid-1990s, squaretrade.com created the largest internet Trustmark system for small businesses. Business to Consumers (B2C) disputes between buyers and sellers on the famous eBay platform was outsourced to Squaretrade, which provides various ADR options, mainly negotiation and mediation of the disputes via web-based applications. $^{40}$

The basic operation of SquareTrade online dispute resolution includes: a guided web-based step-by-step processes, which enable users open a case and follow it towards closure by clicking buttons rather than typing long emails. ${ }^{41}$ One of the essential elements identified by eBay was the need for online trust and confidence; hence, the mission of SquareTrade, which is to 'build trust in online transaction' and reduce the ris

commerce. $^{42}$ The availability of an online resolution system will, undoubtedly excite consumers to keep shopping online. With millions of transactions concluded within 7-days, the probability of dispute is high with causes ranging from 'item not received' or 'item not matching product description'. ${ }^{43}$

The ODR processes adopted by Squaretrade involve multi-tiered mechanism aimed at enhancing accessibility, confidentiality and

\footnotetext{
40 Abernethy, "Building Large-Scale Online Dispute Resolution \& Trustmark Systems."

41 Isabelle Manevy, "Online Dispute Resolution: What Future?" (Université de Paris, 2001).

42 Abernethy, "Building Large-Scale Online Dispute Resolution \& Trustmark Systems."

43 Ibid.
} 
neutrality. The Executive Chairman and co-founder of SquareTrade, Steve Abernethy described the process as follows:

SquareTrade's dispute resolution model was designed to deploy processes of conciliation, mediation and the option of arbitrations or recommended resolution, both as a facilitated service as well as leveraging technology to create a self-service means to help parties solve problems on their own. These processes are based on principles such as clarification, compromise, consensual participation, neutrality, and confidentiality. The model incorporates a two-stage process, beginning with Web-based technology-supported negotiation processes and escalating, if necessary, to professionally facilitated resolutions (primarily mediation). ${ }^{44}$

Despite the take-over of Squaretrade ODR by eBay, the cumulative number of disputes resolved as of 2010 was about sixty million. ${ }^{45}$ Following the successes achieved in the eBay/SquareTrade partnership over the years, the company has developed a Trustmark known as SquareTrade Seal, which is displayed by businesses across the globe to signify commitment to the ODR services offered by SquareTrade. These also act as a pre-dispute ODR agreement for these businesses. However, SquareTrade has since relinquished its ODR systems to eBay and now focusses on gadget warranty, which has been dubbed as the best online protection plan for electronic devices. $^{46}$

\section{Cybersettle.com, SmartSettle and clickNsettle}

Cybersettle.com is an online resolution centre for insurance claims, which is fast becoming routine and more viral in American societies. Established in 1996, the Internet start-up has been mostly successful among its peers. ${ }^{47}$ Specifically, claims involving modest amount, such as traffic accident and legal injuries, are best handled through Cybersettle ODR, although it later engaged in other e-commerce

\footnotetext{
44 Ibid.

45 Ethan Katsh and Leah Wing, "Ten Years of Online Dispute Resolution (ODR): Looking at the Past and Constructing the Future," U. Tol. L. Rev. 38, no. 1 (2006): 19.

46 Omri Ben-Shahar, "One-Way Contracts: Consumer Protection without Law," European Review of Contract Law 6, no. 3 (2010): 221-49.

47 Thomas Schultz, "Connecting Complaint Filing Processes to Online Resolution Systems," Commercial Law Practitioner, no. December 2003 (2003): 307-14.
} 
related disputes. ${ }^{48}$ The possibility of aggravating the meagre claim by protracted legal battle and lawyer's fee makes ODR more appealing as it limits the direct role of legal practitioners.

The mechanisms adopted at Cybersettle, SmartSettle and ClickNsettle through their fully automated ODR system include: online negotiation, online mediation and online arbitration. ${ }^{49}$ Negotiation, which has been the age-long traditional process for insurance companies in settling claims, is aimed at discouraging overdrawn legal battles over insurance claims and encouraging settlement. The most veritable technique used in any fully automated ODR system is 'Blind-bidding', which can be described as an offer of settlement made via a computer programme between disputants. ${ }^{50}$ In the blind-bidding technique, a settlement amount is offered through software and a notification of settlement is sent via email to the other party or his representative, without disclosing the exact amount. This enables the other party to post a counter-offer. The computer programme then returns an aggregate after comparing both offers. The aggregate can be accepted or rejected. Upon acceptance, the case has made progress towards resolution while a rejection will require another round of blind bidding, which must be concluded within fixed numbers of days usually within 30 or 60 days. ${ }^{51}$

Cybersettle is a very good model for e-government ODR which can be used to address disputes and claims between citizens and municipalities. This has helped to enhance productivity, shorten claim life-cycle and reduce legal fees. ${ }^{52}$

\section{ODR in Credit Reporting Disputes}

The use of ODR in financial services delivery has been further exemplified in the activities of credit reporting agencies in the United States. The upsurge in expensive lawsuits against credit bureaus has made the agencies to actively pursue ODR as a method to avoid

48 Charles Brofman, Settled!: The Online Dispute Revolution (The Lexicomm Group, 2008), 123.

49 Goodman, "The Pros and Cons of Online Dispute Resolution: An Assessment of Cyber-Mediation Websites."

50 Thiessen, Miniato, and Hiebert, "ODR and eNegotiation."

51 Goodman, "The Pros and Cons of Online Dispute Resolution: An Assessment of Cyber-Mediation Websites."

52 Available at: http://www.cybersettle.com/about-us. viewed on 16 July 2014. 
expensive lawsuits, which is capable of damaging the company's reputation.

At the core of project financing and risk management is the need to ascertain the credit-worthiness of a financial consumer which is of utmost concern to financial institutions. In order to be assured of the ability of the consumer to pay up, the credit history of consumers is generated from mortgage companies, credit card companies, banks and other creditors to create a detailed credit report. In other words, a good or healthy credit report means a positive response from potential landlord, employers, lenders and finance companies. ${ }^{53}$ The function of credit reporting is either outsourced to registered Credit bureaus or performed as a statutory function of the apex banks in any given financial jurisdiction.

In the United States, there are three main Credit Reporting agencies, ${ }^{54}$ which are authorised under the law ${ }^{55}$ to manage credit history and issue 'credit reports' for various consumers in the country. Despite the available robust legislation in such jurisdiction, incidences of errors in credit scores of consumers have not ceased to plague the industry, as consumers often resort to suing the agencies for colossal damages. In a recent Financial Trade Commission (FTC) study, it was revealed that 25 percent of consumers found errors and inaccuracies, which could affect their credit scores and worthiness to access financing. ${ }^{56}$ Concerns were raised as to the handling of disputes and errors, as mismanagement of disputes have been subject of soaring legal claims against the credit agencies- Equifax, TransUnion and Experian. ${ }^{57}$

53 Mahoney Maureen, "ERRORS AND GOTCHAS: How Credit Reporting and Unreliable Credit Scores Hurt Consumers," 2014.

54 Pursuant to 15 U.S. Code Chapter 41, Subchapter III - Credit Reporting Agencies. Equifax Inc., Transunion Inc. and Experian Inc.

55 The principal enactment which enables the activities of Credit reporting agencies in the United States is the Fair Credit Reporting Act (FCRA) passed in 1970. The act seeks to ensure, fairness, accuracy and privacy of information contained in consumer credit report. The enforcement of the legislation is under the US Federal Trade Commission (FTC).

56 "In FTC Study, Five Percent of Consumers Had Errors on Their Credit Reports That Could Result in Less Favorable Terms for Loans | Federal Trade Commission," Federal Trade Commission, n.d.

57 Laura Gunderson, "Equifax Must Pay \$18.6 Million after Failing to Fix Oregon Woman's Credit Report,” The Oregonian/Oregon Live, July 2013. 
Equifax Online dispute mechanism has been designed in order to fasten the resolution of credit reporting error and avoid expensive law suits.

The Equifax Online Dispute comprises three-steps mechanism for submission of complaint which must be resolved within 30 - 45 days after submission. The online dispute mechanism is one of three other dispute resolution mechanisms. Others are dispute resolution by phone and dispute resolution by mail. Figure 2 shows the interface for submission of new dispute and checking the status or progress of existing disputes.

\section{EQUIFAX Online Dispute}

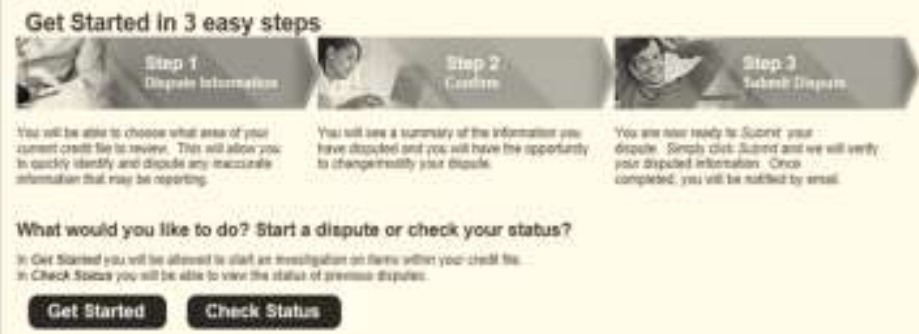

Figure 2: Equifax ODR Interface

Source: Equifax.com

The three steps online mechanism for disputing errors on Equifax credit report includes the following: ${ }^{58}$

Step 1: Consumer supply the required information on the Credit Report update form beginning with the 10-digits confirmation number, personal details (for verification) including a valid email. It is also important to specify what information is incorrect or inaccurate.

Step 2: Copies of any supporting documents (if requested) are to be sent via mail or fax to Equifax address.

Step 3: Applicant is furnished with the result of investigation process after 30 to 45 days via email. The result might make necessary amendments to the credit score. 
The above mentioned steps are specifically designed to grant realtime access to justice for consumers, who intend to file a dispute with respect to the errors contained in their Credit Report. This will ultimately reduce the number of disputes, which might lead to court litigation related expenses.

\section{APPROACHES TO ODR LEGISLATION IN SELECTED JURISDICTIONS}

The need for laws to encourage, facilitate and even enforce the use of ODR mechanisms have been recognised by international entities and organisations such as the European Union (EU), Organization of American States (OAS) and the Organization for Economic Cooperation and Development (OECD) among others. ${ }^{59}$

Although ODR was originally popularised by private initiatives and university pilot projects, there have been few approaches aimed at protecting e-commerce consumers. International efforts towards the promotion of ODR have been a subject of several international fora for quite some time. The need to promote commerce conducted via electronic methods was one of the purposes of the United Nations Commission on International Trade Law (UNCITRAL) Model Law on Electronic Commerce of 1996 - the first international instrument on electronic commerce. ${ }^{60}$ It was followed by the 2001 UNCITRAL Model Law on Electronic Signature (MLES). Rather than being an online dispute resolution instrument, the MLES contained rules related to validity and formation of contracts concluded by electronic means. ${ }^{61}$ The attribution of data messages and non-discrimination against electronic transaction was the focus of the model law which was expected to be adopted by Member States. It laid the foundation for regional and domestic ODR legislations; on the other hand, it serves the interest of various experimentations on ICT-enabled dispute resolution methods.

59 Aura Esther Vilalta, "ODR and E-Commerce," in Online Dispute Resolution: Theory and Practice A Treatise on Technology and Dispute Resolution, ed. Mohamed S Abdel Wahab, Ethan Katsh, and Daniel Rainey (The Netherland: Eleven International Publishing, 2012), 138.

60 "UNCITRAL Model Law on Electronic Commerce," United Nations, n.d.

61 SE Blythe, "Digital Signature Law of the United Nations, European Union, United Kingdom and United States: Promotion of Growth in E-Commerce with Enhanced Security," Rich. JL \& Tech., 2005, 6-8. 
One of such steps towards legalising ODR in a supranational parlance was the OECD guideline for consumer protection in the context of electronic commerce which was issued in 1999. The guideline was aimed at enhancing access to justice, building consumer confidence and creating a balanced relationship between businesses and consumers in commercial relationship. ${ }^{62}$

Following the developments in the dispute resolution landscape and global surge in cross-border e-commerce transactions, the UN Working Group III was commissioned in 2010 to examine possible future works on ODR for cross-border electronic transactions in business-to-business and business-to-consumer disputes. ${ }^{63}$ Series of colloquium are being held and still ongoing in order to gather opinion towards producing an acceptable ODR instrument for the resolution of cross-border disputes in the global market place through ODR. On the other hand, the Association of Southeast Asian Nations (ASEAN) region and African continent are yet to consider moves towards ODR within their domain despite the exigencies of numerous cross-border financial activities.

\section{EU Directives and regulation for ODR}

In actualising the objectives of the UN Working Group III on ODR, the EU took the first known step towards a supranational ODR legislation. Several directives and regulations were adopted between 2004 and 2013 for the full implementation of practical and binding ODR framework to begin in the year 2016. From 15 February 2016, the ODR platform developed by the European Commission has been made accessible to online consumers and traders.

It is pertinent to note the legal effect of directives and regulations under the corpus of EU Parliament. According to Hartley, under Article 249 (ex 189) of the EC Treaty, Regulations are essentially legislation addressed to all Member States and applies fully without the need for national legislation. On the other hand, Directives to Member States are meant for their implementation at a specific date

62 oecd, "Recommendation of the OECD Council Concerning Guidelines for Consumer Protection in the Context of Electronic Commerce," n.d.

63 Report of the United Nations Commission on International Trade Law, Fortythird session (21 June-9 July 2010) General Assembly Official Records. U.N. Doc. A/65/17; GAOR, 65th Sess.,Supp. No. 17 (2010) [hereinafter Rep. of the 43d Sess.]. 
or time frame. While Regulations have direct effect, Directives 'have no automatic direct effect' and are not binding on individuals until national authorities draw up domestic legislations. ${ }^{64}$

The road to ODR legislation in the EU was quite lengthy and gradual. Initial steps were aimed at protecting online consumers within the EU cyberspace following the adoption of Directive 2009/22/EU 'for the protection of consumers' interests' within the Member States of the EU. ${ }^{65}$ This was followed by Directive 2013/11/EU which enhances ADR coverage and awareness for all consumers through registered 'ADR entities ${ }^{66}$ within the Member States of the EU. Article 11 of the Directive also laid the foundation for ODR legislation through the recognition of online commerce and unified ADR procedures within the EU. ${ }^{67}$ Furthermore Article 12 provides that availability of ADR is a precondition for the proper functioning of the ODR platform. A specific legislation on ODR is Regulation 524/2013 which provides for the establishment of an ODR platform which offers consumers and traders a single point of entry for the out-of-court resolution of online disputes. ${ }^{68}$

Some of the salient provisions of the EU Directives and Regulation on ODR include the following:

i. ODR Platform: Chapter II of the EU ODR Regulation provides for an ODR platform for submission and management of consumers' complaints. The platform is capable of providing electronic case management tool free of charge, which enables the parties and the ADR entity to conduct the dispute resolution procedure online. This platform also delivers multilingual system which accommodates the several languages spoken within the European Community. Therefore the language barrier in the resolution of disputes is removed. In addition, an electronic link

64 Trevor C Hartley, The Foundations of European Community Law: An Introduction to the Constitutional and Administrative Law of the European Community (Oxford University Press, USA, 2007), 102.

65 "Directive 2009/22/EC of the European Parliament and of the Council of 23 April 2009," Official Journal of the European Union, n.d.

66 Ariticle 20(2) "Directive 2013/11/EU of the European Parliament and of the Council," Official Journal of the European Union, n.d.

67 Ibid.

68 "Regulation (EU) No 524/2013 of the European Parliament and of the Council," Official Journal of the European Union, n.d. 
to the platform is to be provided to consumers by all consumer and business associations in Member States.

ii. ADR Entities: Chapter II of the 2013 Directive sets specific requirements for ADR entities and procedures. All ADR entities must be capable of processing offline and online ADR procedures. The entities must also be able to resolve disputes and complaints within 90 calendar days from the receipt of the complaint file including all relevant documentation.

iii. National Contact Point: Pursuant to Article 7 of the Regulation, each Member State is expected to provide the details of ODR contact points. The main function of the contact point is to provide support and facilitate communications between parties and ADR entities for the resolution of disputes relating to complaints submitted through the ODR platform. ${ }^{69}$

iv. Exclusion: The Regulation does not apply to sales or service contracts concluded offline and to disputes between traders.

v. Enforcement: Enforcement of decisions shall be via cooperation between ADR entities and national authorities entrusted with consumer protection in Member States. ${ }^{70}$

The full implementation of the Regulation was made subject to the submission of the first list of ADR entities by $9^{\text {th }}$ January 2016 and available for use as of 15 February 2016 to allow for a maximum geographical and sectoral coverage across the EU. In addition, the Regulation provides for a yearly report to access the functioning of the ODR platform as well as a three-year review of its operation. At present, the ability of the EU Regulation to ensure online resolution of disputes and complaints is yet to be fully harnessed by consumers and traders.

\section{Organisation of American States - OAS}

In the Americas, there have been similar attempts to establish a practical regional legal framework for ODR under the auspices of

69 Ibid.

70 "Directive 2013/11/EU of the European Parliament and of the Council." 
OAS comprising the United States, Canada, several Latin American and few Caribbean countries. ${ }^{71}$ In Latin America and the Caribbean, ODR is still in its infant stage despite the unprecedented boom in ecommerce. $^{72}$

The most potent responses on ODR in the Americas comprise private start-ups and public ODR platforms. The main distinguishable factors between public and private ODR are funding mechanism and accessibility. ${ }^{73}$ Among such initiatives is Concilianet which is hosted by Office of the Federal Prosecutor for the Consumer (PROFECO), Mexico. $^{74}$ The platform, which boasts of simple and clear resolution process, helps to address complaint irrespective of nationality of the consumer. In addition, enforceability within Mexico is not a barrier due to the immense support from the national judiciary. ${ }^{75}$

Similarly, the National Consumer Service (SERNAC) in the Republic of Chile has established an online mechanism to protect consumers from unfair trade. Although the body is statutorily empowered to institute class action or litigation to protect consumers, ${ }^{76}$ it has since added ADR to the list of tools in its domain. $^{77}$

In 2003, there was an attempt within the Organisation of American States (OAS) region through the $7^{\text {th }}$ Inter-American Specialized Conference on Private international Law (CIDIP VII) to unify consumer protection and e-commerce framework. Several draft proposals were submitted by Canada, Brazil, United States among others. ${ }^{78}$ At a later meeting of the CIDIP VII, Canada and other countries submitted various proposals on the forum for litigation of consumer claims. In February 2010, the U.S. submitted a revised

71 "Member States-OAS - Organization of American States," 2009.

72 Albornoz, "Feasibility Analysis of Online Dispute Resolution in Developing Countries."

73 Scott Shackelford and Anjanette Raymond, "Building the Virtual Courthouse: Ethical Considerations for Design, Implementation, and Regulation in the World of ODR," Wisconsin Law Review, 2014.

74 "Concilianet," n.d.

75 "OAS-Building a Practical Framework for Consumer Protection,” n.d.

76 Carley Doyle, "Consumer Access to Justice: A Comparison of Consumer Class Action Litigation in the United States of America and the Republic of Chile," Willamette J. Int'l L. \& Dis. Res. 22 (2014): 137.

77 "SERNAC-Servicio Nacional Del Consumidor | No Se Encontró La Página," n.d.

78 Albornoz, "Feasibility Analysis of Online Dispute Resolution in Developing Countries." 
proposal on building a practical framework for consumer protection through an OAS-ODR Initiative for electronic resolution of crossborder e-commerce consumer disputes, to promote confidence and provide quick resolution and enforcement of disputes across borders, languages, and different legal jurisdictions. ${ }^{79}$ Currently, the state of work on ODR in the OAS region relies on the strength of the U.S. proposal which can been summarised as follows:

i. The process utilises ODR technology to provide negotiation, mediation and arbitration for cross-border consumer claims up to USD $\$ 10,000$.

ii. The buyer retains full rights to pursue other forms of redress, including protection programmes provided by third party organisations or payment channels.

iii. Both parties also retain the right to be represented by an attorney, though representation is not mandatory.

iv. Under this process, a buyer may file a cross-border complaint online against a registered vendor if they both reside in countries that have agreed to participate in the system.

$\mathrm{v}$. The default language of communication during the process will be the language used to conduct the transaction in the first place.

The Memorandum of Understanding on OAS-ODR identifies and gives specific role to the following key players: the buyer and vendor, the neutral, the ODR provider, the national consumer authorities and the Central Administrator. Although the document is still far from ready for implementation, it serves as a bold step towards consumer protection in the region.

\section{Other international efforts for online consumer protection}

Outside the EU and OAS region, there have been some forms of international cooperation for online consumer protection. In the ASEAN and Sub-Sahara Africa, there is no visible presence of online regulated environment for dispute resolution and consumer protection. According to a report by the Economic Research Institute for ASEAN and East-Asia (ERIA), there was a multi institutional

79 Rule, Rogers, and Duca, "Designing a Global Consumer Online Dispute Resolution (ODR) System for Cross-Border Small Value-High Volume Claims-OAS Developments." 
plan to form a regional ODR framework within the region. Other institutional partners include the Global Business Dialogue on Electronic Commerce (GBDe) based in Japan, the Consumer Confidence Issue Group (CCIG) and the International Consumer Advisory Network (ICA-Net) ${ }^{80}$ The main aim of the partnership was to provide a secure and safe e-commerce marketplace within the ASEAN region. Although it is on record that a trial version of an ODR platform was designed by Japanese e-commerce consumer protection agency, little is known about the actual deployment of the ODR mechanism. Therefore, these efforts have not been able to deliver a practical online protection for consumers. Although few countries in the region have introduced ODR legislations, crossborder ODR is still a mirage within the region. The various works highlighted in the ERIA report show a great deal of e-commerce information sharing among countries. There is the need to build upon the current level of information sharing and cross-border e-commerce to facilitate regional ODR framework and mechanisms in the region.

\section{CONCLUSION}

There is still a great deal of learning for lawmakers, lawyers and dispute resolution experts in handling emerging form of disputes in the $21^{\text {st }}$ century. From the foregoing discussion, it is thus clear that a comparative analysis of trends and traditions in ODR legislations show the use of several approaches in enabling ODR for e-commerce at both national and regional levels. These approaches include single national ODR platform, regulated mechanisms of the European Community and National collaboration by public ODR providers in the OAS region. There are currently no concrete steps towards ODR legal framework in the ASEAN region, Gulf countries and in the African continent. Therefore, consumers have to rely on customer feedback mechanisms, onerous return/refund policies and consumer protection regulations.

On the other hand, some private initiatives in credit reporting and other sectors in the EU, the United States and Canada proffer a practical alternative for electronic consumers' dispute resolution governance. While ODR mechanisms have been proven to provide

80 "Establishment of a Secure and Safe E-Commerce Marketplace 2008," ERIA Research Project Report No.3-2, 2009. 
neutral, quick and cost-efficient redress for consumers, ability to resolve disputes and complaints online without the need for traditional offline contact seems to be the most effective means for providing access to justice for online consumers. Hence, there is the need for a legal framework for the implementation of this relatively new ICT-driven innovation in various jurisdictions particularly in the developing world. 